\title{
Modelo para la gestión de la innovación tecnológica en el sector inmobiliario
}

\section{Management model for technological innovation in real estate}

\author{
Barrio Daniel*1, García Salvador*, Juan Pablo Solís * \\ * Tecnológico de Monterrey ITESM. MÉXICO
}

\begin{abstract}
Fecha de recepción: 01/ 07/ 2011 Fecha de aceptación: 01/ 09/ 2011

Resumen

PAG. 353 - 368

En la actualidad, en México no se ha implementado algún modelo para la gestión de la innovación tecnológica, la cual se refiere a la creación o modificación de un producto o proceso de manera práctica que sea útil para obtener beneficios económicos al introducirla al mercado, en el sector inmobiliario. Esto ha ocasionado que los esfuerzos en dicha área sean individuales y poco repetibles, sin embargo, se ha reconocido en dicho sector la necesidad de implementar procesos para el desarrollo de innovación tecnológica con el fin de lograr una diferenciación ante la creciente competencia. Debemos entender la gestión de la innovación tecnológica como el proceso orientado a organizar los recursos con la finalidad de crear conocimiento, procesos y productos. En el presente artículo se pretende atacar esta necesidad implementando un Modelo para la Gestión de la Innovación Tecnológica (MGIT) aplicado al sector inmobiliario, tomando en cuenta las tendencias de evolución en las tecnologías de la construcción y las características distintivas de este sector productivo, con la finalidad de facilitar los lineamientos a seguir para lograr un proceso de innovación tecnológica que disminuya tiempo y costo. El MGIT se valida con un caso de aplicación para la creación de un sistema nuevo de fachadas para edificios de vivienda residencial.
\end{abstract}

Palabras Clave: Modelo gestión, innovación tecnológica, tendencias

Abstract

There has not been implemented, in Mexico, a model for the management of technological innovation, which refers to the creation or modification of a product or process in a practical way that is useful to generate economic benefits by introducing the innovation to the market. This has led to isolated and irregular efforts in this area; however, the real state sector has recognized the need to implement such management of technological innovation in order to achieve differentiation. Management of technological innovation must be understood as the process to organize resources in order to create knowledge, processes and products. This article is an effort to implement a Model for the Management of Technological Innovation (MGIT) applied to the housing sector. MGIT takes account of the trends of development in building technologies and the features of this productive sector. The purpose of this effort is to reduce time and cost on the process of seeking for technological innovation. The MGIT is validated with a case of application for the creation of a new system of building facades for residential housing.

Keywords: Management model, technological innovation, tendencies

\section{Introducción}

\footnotetext{
1 Autor de correspondencia / Corresponding author: E-mail: dbarriom@gmail.com
}

\section{Introduction}

Housing construction has been, since the beginning of our existence, one of the fundamental activities of the society due to the intrinsic need to seek refuge to fight climate adversities. Over the years, the real estate industry has evolved to better meet the needs of people. In recent years, real estate construction projects have been developed based on traditional technologies, in-situ production of almost all parts of the building. 
These traditional technologies are inefficient with regard to time and effort-consuming for its implementation.

This article is based on the need for innovation in the housebuilding sector in order to present a Management Model for Technological Innovation in this sector (MGIT). As a preliminary information, are seen concept and innovative techniques, other models applied to various productive sectors and trends in the construction sector.

This paper presents a Model to manage efficiently and effectively the process of technological innovation in real estate. The model must be aligned with innovation trends in construction and must take into account the specific characteristics of this sector for the correct application of the various tools available to control and monitor the process. Similarly, it is presented a case of application for the creation of a new system of building facades of residential housing for Mexican market.

\section{Preliminary}

2.1 Concepts and innovation techniques Definition and Types

According to the Royal Spanish Academy, Innovation is to "Create or modify a product, and to introduce it into a market". Melissa Schilling (2008) goes beyond this definition by stating that the products are not only prone to innovation, but so are the processes. Then a clearer definition is the creation or modification of a product or process in a practical way that is useful for economic benefit upon introducing it to the market.

To achieve innovation, one must follow a series of stages that begin with the generation of new ideas. These ideas are the product of both individual and organizational creativity. Creativity comes mainly from the organizational efforts on Research and Development $(I+D$, in Spanish). The concept of research and development can be defined as the range of activities which go from knowledge acquisition to the generation of commercial implementations (Schilling, 2008).

Depending on the scope and application of innovation there are several types: 
- Products vs. Processes

- Radical vs Incremental

- Architectonic vs of Component

The types of innovation are not independent of each other as it results common to share dimensions.

\section{Innovation tools and techniques}

Among the techniques for managing innovation, it is possible to find a wide range of tools. The optimal technique depends on the application area that one wants to use. The following explains only the techniques that have a greater potential in the possible application of technological innovation projects in real estate in Mexico.

Tabla 1. Técnicas y herramientas de Innovación

Table 1. Innovative techniques and tools

\begin{tabular}{||l|l||}
\hline \hline Herramienta/Tools & Descripción/Description \\
\hline $\begin{array}{l}\text { Técnicas de Creatividad } \\
\text { Creativity techniques }\end{array}$ & $\begin{array}{l}\text { Principio básico de la innovación. La creatividad debe de ser flexible, original y fluida. } \\
\text { Basic principle of innovation. Creativity shall be flexible, original and fluid }\end{array}$ \\
\hline Brainstorming & $\begin{array}{l}\text { Se basa en 1) generación de gran cantidad de ideas y 2) diferir el juicio de las mismas hasta el final } \\
\text { de la actividad. } \\
\text { It is based on 1) the generation of great amount of ideas and 2) to defer the ideas judgment until } \\
\text { the end of the activity }\end{array}$ \\
\hline $\begin{array}{l}\text { Pensamiento Multidireccional } \\
\text { Multidirectional Thinking } \\
\text { de lo que el pensamiento orientado al patrón del pensamiento habitual pudiera. } \\
\text { It leads thinking under no-traditional way in order to obtain results more relevant than from usual } \\
\text { thinking patterns }\end{array}$ \\
\hline $\begin{array}{l}\text { 6 sombreros Pensamiento } \\
6 \text { huts-thinking }\end{array}$ & $\begin{array}{l}\text { Fomenta el pensamiento lateral. Cada sombrero representa un estilo diferente de pensamiento y } \\
\text { es representado en forma gráfica con un color. } \\
\text { It encourages lateral thinking. Each hut represents a different style of thinking and it is graphically } \\
\text { represented with a color }\end{array}$ \\
\hline TRIZ & $\begin{array}{l}\text { Metodología altamente estructurada para resolver problemas basados en ciencia y tecnología que } \\
\text { requieren un alto grado de creatividad e inventiva, los cuales pueden ser de cualquier área } \\
\text { tecnológica. } \\
\text { Highly structured methodology used to solve problems based on science and technology that } \\
\text { demands high levels of creativity and inventiveness }\end{array}$ \\
\hline $\begin{array}{l}\text { Despliegue Función de Calidad (QFD) } \\
\text { Quality Function Deployment }\end{array}$ & $\begin{array}{l}\text { Proceso sistemático que ayuda a planear, comprender y especificar claramente los requerimientos } \\
\text { ynecesidades del cliente, y a integrar dichas necesidades en los productos. } \\
\text { Systematic process that contributes to plan, understand and clearly specify demands and requirements } \\
\text { from the client and to integrate such needs to products }\end{array}$ \\
\hline
\end{tabular}

As mentioned repeatedly, technological innovation is key to achieve a competitive advantage in a present. rapidly changing environment. Today in a wide range of industries, more than a third of their sales come from products developed within the last five years (Schilling, 2008). 
2.2 Other models for management of technological innovation

Innovation is a paradigm in its very existence, althow popular innovation is described as a free process that does not have rules and restrictions of specific plans in order to promote creativity, there are numerous studies that show how companies in the frantic race to innovate, rush in new product development strategies without having well-developed operational plans, which results in projects that exceed the resource capabilities of enterprises and in project failure. For these reasons, there is a need for models for the management of technological innovation (Schilling, 2008).

Some of the models which exist in literature for other productive sectors are: "Innovation Management in 8 steps" (Asociación de la Industria Navarra, 2008); 5 pilars BCG model (Galindo, 2008); and the one of companies and Information Technology(Scantlebury \& Lawton, 2007). The first two models are completely generic and include everything from strategic step to knowledge protection. The third model is specific to businesses in the sector of information technology and focuses on the operational stages leaving out part of strategies and knowledge protection.

\subsection{Trends in construction innovation}

New Building Materials

According to García (2008) new building materials follow the trend of light weight, easily transportable, simplicity of assembly and installation, excellent behavior against corrosion, molded in large part, self-cleaning with rainwater, no interference with electromagnetic waves present, highly resistant to fire and they serve as excellent thermal insulation.

There is a direct relationship between the new materials and construction productivity, Goodrum, Zhai y Yasin (2009) studied the impact of different qualities and characteristics of new materials in the overall productivity of more than 100 buildings between 1997 and 2004. It was found that activities undergo significant changes in the technology of materials, also have farreaching improvements in the productivity of both labor and total factor productivity in construction. Another result was that the lower the weight of materials, greater productivity index detected. 
New Construction Technology: Prefabrication Prefabricated construction system is based on the design and production of components and subsystems manufactured in series in a factory outside of its final location and that in its final position, after a simple installation phase, accurate and laborious, form all or part of a building or construction (Gómez Jáuregui, 2009). Currently the construction industry is migrating from traditional systems to the use of prefabrication to control the high variability of the traditional construction process. Due to the passage of time, production techniques evolved from the use of large precast concrete (closed systems) to the mass production of building components catalogs. A good measure to determine the degree of prefabrication used in a project is to assess the amount of waste as well as waste generated during the construction of the project; to more waste, lower prefabrication rate.

Domotics and Robotics

The term domotics come from a mixture of domestic and computer words, it is the discipline that studies the development of intelligent infrastructure and information technology in buildings. Infrastructure is said to be intelligent because it is capable of processing data (Quinteiro, Lamas, \& Sandoval, 2005). Domotics is fully oriented to the stage of service of a building.

Until recently, housing was provided with the minimum facilities, however, currently are being used more sophisticated facilities in order to increase comfort, safety, energy conservation, communication and flexibility. The main application areas of Domotics are comfort, security and energy management.

Robotics differs from domotics by its field of application. While the domotics focuses on the automation of property for the benefit and convenience of the user, robotics is the use of automated machines for construction activities of a property. A robot is a "machine that performs automated and complex operational sequences that can monitor its performance, are self-regulated and automatically correct its operation" (I.A.A.R.C., 2010). 


\section{Quality Systems and Lean Construction}

Another trend in the construction industry refers to new systems of project management. These include efforts from project design, to implementation and postsales. Luna y González (2007) tested to classify and categorize the various models of quality according to the complexity and level of application in the construction industry.

Extending the Lean Construction theme, this philosophy was adapted to the construction by Koskela in $\mathbf{2 0 0 0}$ to identify that the construction can be viewed as a process flow management. However, this differs from the manufacturing flow by the unpredictable nature of construction projects (Bertelsen, 2004).

Lean Construction is a new philosophy oriented toward production management in construction, which main objective is to eliminate activities that add no value. This philosophy has caused a revolution in the way that the construction projects are carried out, since they include everything from design, to the procurement of materials, the construction process and the finished product. The construction extends lossless main objective of minimizing waste, to dictate specific techniques to carry out a project (Lean Construction Institute, 2008).

\section{Model for technologycal innovation management at real estate sector (MGIT)}

This model for the management of innovation provides a useful and orderly system for searching and creating innovation in real estate. As any system it must contain a data input stage, a processing stage and a result or output.

MGIT is divided in two big stages: 1 ) Identification of Ideas and 2) Development of the Project. The first stage concerns the investigation of areas of opportunity and existing solutions, while the second stage is based on a cycle that extends from the definition of parameters to final implementation and protection of knowledge. Here follows the description of each MGIT stage. 


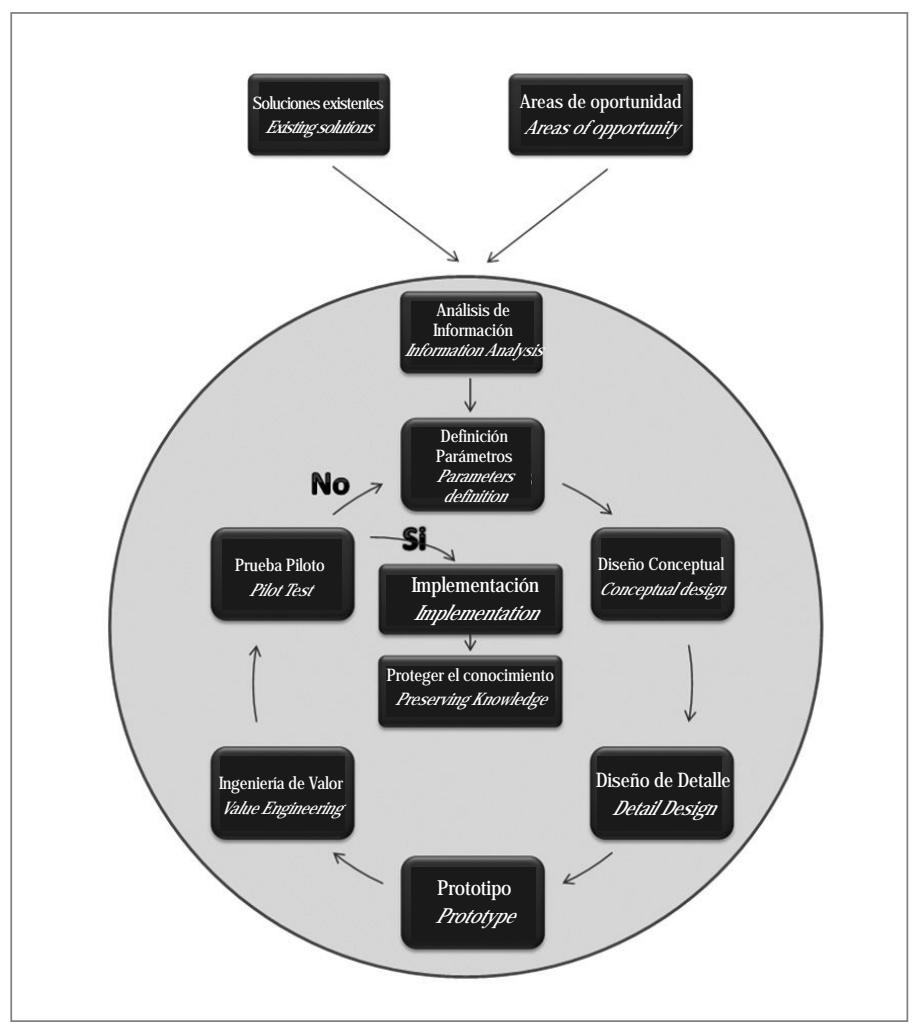

Figura 1. MGIT

Figure 1. MGIT

3.1 Part 1.- Identification of ideas 3.1.1 Areas of Opportunity

At this step must be used creativity as a source of idea generation, it is the origin of all innovation process, it is a key point that sustains innovation strategies of the organizations. This step consists of an orderly process for generating ideas. A brief description:

- To know the current situation. A personal administrative and operational questionaire is recommended in order to understand the current ecommended in order to understand the current $s$ and construction activities, to the use of prefabricated, quality systems and current problems.

- Based on the above information, it is defined a way forward. It must be selected only the main course leaving pending the specific solutions that will be proposed.

- To deepen the theme chosen. A second questionnaire is performed, aimed towards the problem and course chosen in the previous section. It seeks to find specific problems, possible solutions and recommendations.

- Make use of the TRIZ methodology to find which parameters and inventive principles are useful in solving the problem. 
Tabla 2. Áreas de oportunidad

Table 2. Areas of opportunity

\begin{tabular}{||l|c|c|c||}
\hline $\begin{array}{c}\text { Área de Oportunidad } \\
\text { Areas of opportunity }\end{array}$ & $\begin{array}{c}\text { Situación a Mejorar } \\
\text { Situation to improve }\end{array}$ & $\begin{array}{c}\text { Parámetros TRIZ(39) } \\
\text { Parameters TRIZ(39) }\end{array}$ & $\begin{array}{c}\text { Principios de Inventiva TRIZ(40) } \\
\text { Inventive Principles TRIZ(40) }\end{array}$ \\
\hline & & & \\
\hline & & \\
\hline
\end{tabular}

\subsubsection{Existing Solutions}

At this step we review the state of the art solutions in the market to resolve the way forward. We recommend using a form of technical properties to collect information for each existing solution be found.

3.2 Part 2.- Development of the project

3.2.1 Analysis of Collected Information

The objective of this step is to find important features to consider in product innovation. The information obtained in the step of ideas Identification is analyzed. Below there is a table where the first section list the necessary features detected in the research of Opportunity Areas and Existing Solutions. In the area of the Weighting Matrix table is compared the hierarchy of each property in front of the others. It should be noted the letter of identification of the most important feature in each box. If they are of equal importance both letters are written. The total column adds each letter in the Weighting Matrix to finally obtain the \% share of each feature. 
Tabla 3. Análisis de características importantes

Table 3. Analysis of important features

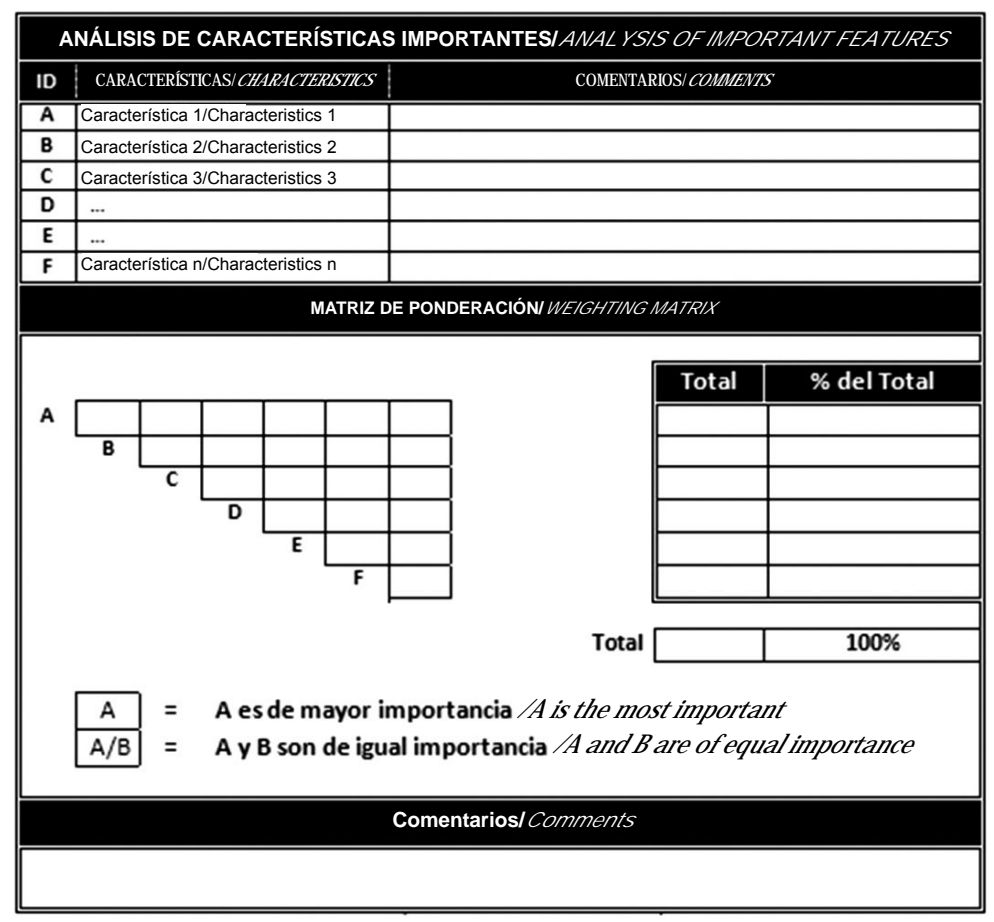

Finally are listed in ascending order each feature with its participation percentage.

\subsubsection{Define Parameters of Innovation}

At this step are defined the parameters to be met by the proposed innovation. These parameters should include range of values that frame the scope of the project. It is important that they are aligned with the important features obtained from the previous step. Parameters must be considered both product and process. Similarly, one should consider whether one wants to meet any specific performance standard.

\subsubsection{Conceptual Design}

The conceptual design should answer the following question: How are going to be integrated the different parameters found in the same solution? At this point of the process it is not intended to arrive at a final design, it's just a first approach to the proposed solution.

It is recommended to use a standardized format for the different ideas that may arise, in order to systematize the process. 


\subsubsection{Detailed Design}

This point is perhaps the most laborious of the MGIT as it should detail the solution of the previous section including product design and process.

\section{- Product Design}

o Structural Design.- Must be made taking into account the current regulations for the method of analysis and the type and magnitude of loads to be considered (wind, earthquake, etc.).. Consider also the loads generated in the installation process.

o Construction Plans.- Include all necessary drawings and diagrams for the manufacture of the product. Include details of: mounting, seals or joints, floor plan, cut and detail.

o Technical specifications.- Each element should describe the product in terms of dimensions, materials, quantities and other technical characteristics. It also should include performance measures to assess the quality of the product and its parts.

o Direct Cost Analysis .- Obtain and submit the cost of manufacturing, transportation and installation.

\section{- Process Design}

o Manufacturing Process .- Conceptually describe the sequence of activities in the manufacturing stage. Include inputs and outputs of each process.

o Installation Manual .- Must include description of best practices for transport, storage, assembly and final details of joints and parts.

\subsubsection{Prototipe}

Since it has a detailed design innovation, one can proceed with the development of a prototype. There are two types of prototypes: Virtual and Real. Whatever the chosen prototype, it should be able to display properties and characteristics to be evaluated among which there are:

- Concept, stile and aspect

- Volume, mass and general properties

- Sizing and modulation

- Installation conditions, ergonomics

- Strength of materials

- Thermal resistance

- Interaction of the various materials used 


\subsubsection{Value Engineering}

Value engineering presents a structured and ordered method to perform evaluations of the different alternatives. This study aims to locate, on a scale of value, the proposed innovation over existing solutions.

The input data are existing solutions found in step 1.2. Following that, important characteristics are evaluated for each existing solution and for the innovation product. Finally, in a performance table it is shown the index value of each proposal (score / Cost).

Tabla 4. Tabla de Desempeño

Table 4. Performance Table

\begin{tabular}{||c|c|c|c|c|c||}
\hline \multicolumn{5}{|c|}{ TABLA DE DESEMPEÑO / PERFORMANCE TABLE } \\
\hline $\begin{array}{c}\text { Alternativa } \\
\text { Alternative }\end{array}$ & Total & $\begin{array}{c}\text { \% Mejora } \\
\text { Improvements }\end{array}$ & $\begin{array}{c}\text { Costo Total } \\
\text { Total cost }\end{array}$ & $\begin{array}{c}\text { Índice de Valor (P/C) } \\
\text { Value index (P/C) }\end{array}$ & $\begin{array}{c}\% \text { Mejora Índice Valor } \\
\text { Best Index value }\end{array}$ \\
\hline Sistema Actual/Current System & & & & & \\
\hline Alternativa 1/Alternative 1 & & & & & \\
\hline Alternativa 2/Alternative 2 & & & & & \\
\hline Alternativa 3/Alternative 3 & & & & & \\
\hline
\end{tabular}

This step is when the first decision is made regarding whether the newly created product is good enough to go ahead with the MGIT or if changes are needed in the detailed design of the product.

\subsubsection{Pilot Test}

Once approved the proposal for technological innovation, it is implemented in some area of the enterprise to monitor its performance and check throw periodic reviews and determine if one is really obtaining the expected results.

During the implementation of the pilot one should monitor the features to ensure that they are within the range of operation defined by technical specifications. These features should include among others: time, cost, quality, process, assembly and transport.

The person responsible for monitoring the pilot must know the important features of the innovation in order to evaluate them and provide comments.

If the pilot does not have the expected results for innovation, it must be done a re-evaluation of the definition of parameters. 
A recommendation to evaluate the prototype is to use the analysis methodology of Failure Mode and Effects (FMEA). This methodology is useful to find the faults, their causes and effects. Similarly, it helps on the prioritization of each one to focus on the main ones.

\subsubsection{Final implementation}

The final implementation is the result of technological innovation. At this stage there is already a finished product and the errors found in the pilot have been corrected. Such corrections shall cover the observations and deficiencies detected with regard to: Time, cost, quality, process, assembly and transport.

Even if methodology proposed here is a useful tool for the systematic generation of technological innovations, it is highly advisable to carry out periodic reviews of the performance of the implemented system. This with the purpose of promoting philosophy of continuous improvement.

\subsubsection{Knowledge Protection}

For each type of invention it was created a specific form of protection, providing varying degrees of exclusivity rights on it. Most technological innovations are within the operating range of the patent.

This step seeks to protect through national and international agencies, the exclusive rights of newly created knowledge.

\section{Aplication of MGIT}

\subsection{Description}

The case study application consists of developing a facade for buildings of residential housing for the Mexican market. It is formed a multidisciplinary team of 5 persons with members who have knowledge in costs, structures and design. The project is carried out from January to May 2011.

Assumptions and restrictions are:

- Prefabricated industrialized system

- Consider modulation and standardized size

- Consider weight component (light system)

- Single layer, bilayer or tri-layer

- Vertical or horizontal Intern

- Conventional, non conventional or alternative materials 
- Incorporation of sustainability concepts

- Direct cost \$1.000 dlls/m2 (estimated)

Due to the limited time to develop the project, it will be done only for the prototype stage, remaining pending the implementation of a pilot and the assurance of newly created knowledge.

\subsection{Identification of ideas}

In the ideas identification stage it was found an area of opportunities able to improve productivity on installation minimizing the use of heavy equipment, creating simple connection elements and modifying sizing and modulation. Similarly, the need to increase customer's comfort was found, increasing thermal and acoustic insulation.

Existing solutions were found:

- Tilt-up walls

- Slender Wall from Easi-Set company

- ExoTec \& Versilux Facade Panel from James Hardie company

4.3 Development of the project

In the second stage of MGIT it was found that the important features were:

- Simplicity of Connections

- Facility of installation

- Thermal Insulation

- Lightness

- Product Sustainability

The product obtained was called PanelTec. which is a modulation system with a $\mathbf{1 . 2} \mathrm{m}$ wide and $\mathbf{3 . 0}$ meters high. On its outer side it was used a product based on $60 \%$ recycled plastic and $40 \%$ kaolin. The structure profiles consists on cold rolled steel $10 \mathrm{~cm}$ thick. The inside panel is a panel drywall or cement, depending on their area of application. PanelTec's interior consists of polyurethane foam padding.

When performing Value Engineering, improvements were obtained in the index value over other alternatives analyzed. 


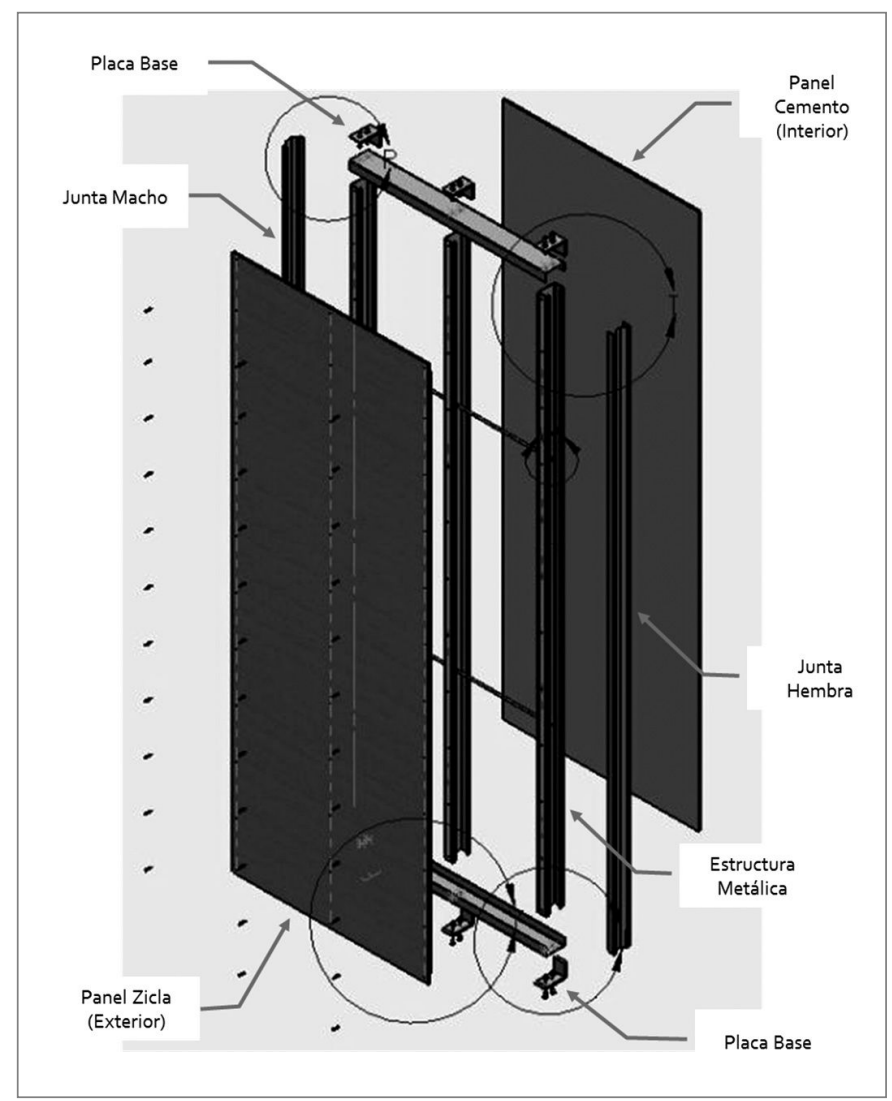

Figura 2. PanelTec

Figure 2. PanelTec

Tabla 5. Tabla de Desempeño PanelTec

Table 5. PanelTec Performance Table

\begin{tabular}{||c|c|c|c|c|c||}
\hline \multicolumn{7}{|c|}{ TABLA DE DESEMPEÑO / PERFORMANCE TABLE } \\
\hline $\begin{array}{c}\text { Alternativa } \\
\text { Alternative }\end{array}$ & Total & $\begin{array}{c}\% \text { Mejora } \\
\text { Best }\end{array}$ & $\begin{array}{c}\text { Costo Directo [DIIs/m²] } \\
\text { Direct Cost [DIIs/m²] }\end{array}$ & $\begin{array}{c}\text { Índice de Valor (P/C) } \\
\text { Index value (P/C) }\end{array}$ & $\begin{array}{c}\% \text { Mejora Índice Valor } \\
\text { Best Index value \% }\end{array}$ \\
\hline SlenderWall & 328.8 & & $\$ 270$ & 1.22 & \\
\hline ExoTec \&Versilux & $\mathbf{2 7 7 . 0}$ & $\mathbf{- 1 5 . 8} \%$ & $\mathbf{\$ 2 5 0}$ & $\mathbf{1 . 1 1}$ & $\mathbf{- 9 . 0} \%$ \\
\hline Tilt-up & $\mathbf{2 8 8 . 0}$ & $\mathbf{- 1 2 . 4 \%}$ & $\mathbf{\$ 1 5 0}$ & $\mathbf{1 . 9 2}$ & $\mathbf{5 7 . 7 \%}$ \\
\hline PanelTec & $\mathbf{3 9 7 . 0}$ & $\mathbf{2 0 . 7} \%$ & $\mathbf{\$ 1 8 5}$ & $\mathbf{2 . 1 5}$ & $\mathbf{7 6 . 2} \%$ \\
\hline
\end{tabular}




\section{Conclusions}

Application of MGIT case created a system for building facades of residential housing for the Mexican market.

It was decided that the product would be an incremental innovation, which would improve the issues that cause major problems in current facade systems. Incremental was chosen because radical innovations have a longer development period and the time did not allowed this type of innovation.

The point of greatest importance, and where mayor efforts were faced, was conceptual design. It is here where one should think about how to comply with innovation parameters. To achieve this different techniques were used such as Brainstorming and team meetings to get ideas of the specialty of each member of the team. Once agreed the conceptual design each member in his specialty work weekly to show progress and resolve problems and questions that arose as they advanced in product development.

The lessons learned during the implementation of MGIT were that the process helps to align efforts and manage resources used to avoid spending too much time or too much effort on early stages. Similarly, it was observed the importance of a multidisciplinary balanced team, ie it should have a member with knowledge in each required area for product development. If there is not the knowledge or ability, it is necessary to rely on somebody external.

\section{Referencias / References}

Asociación de la Industria Navarra. (2008), La gestión de la Innovación en 8 pasos. Gobierno de Navarra. Navarra: ANAIN Agencia Navarra de Innovación.

Bertelsen S. (2004), Lean Construction: Where are we and how to proceed? Lean Construction Journal, 1(1), 46 - 69. Galindo R. (2008), Innovación de Productos: Desarrollo, investigación y estrategias de mercado. México: Trillas. García S. (2008), Manual de Gestión de la Innovación Tecnológica en la Construcción. Manual de Clase. Monterrey: ITESM Campus Monterrey.

Gómez Jáuregui V. (2009), Habidite: viviendas modulares industrializadas. Informes de la Construcción, 61(513), 33-46. Goodrum P., Zhai D. y Yasi M. (2009), Relationship between Changes in Material Technology and Construction Productivity. Journal of Construction Engineering and Management, 135(4), 278-287.

I.A.A.R.C. (2010), Quick Guide to Construction Automation and Robotics. Recuperado el 12 de abril de 2010, de International Association for Automation and Robotics in Construction: http://www.iaarc.org/frame/quick.htm 
Lean Construction Institute (2008), What is Lean Construction? Recuperado el 09 de septiembre de 2010, de Lean Construction Institute: http://www.leanconstruction.org/

Luna K. y González C. A. (2007), Implemetación de Sistemas de Calidad en la Industria de la Construcción: Hacia un modelo cualitativo de evaluacion. 3(1), 412 - 435.

Quinteiro J., Lamas J., y Sandoval J. (2005), Sistemas de Control para Viviendas y Edificios: Domótica. Madrid: Thompson Paraninfo.

Scantlebury S. y Lawton C. (2007), Gaining a Seat at the Innovation Table. Boston: The Boston Consulting Group.

Schilling M. (2008), Dirección Estratégica de la Innovación Tecnológica. Madrid: Mc Graw- Hill. 